\title{
Picture Exchange Communication System (PECS): A strategy to improve children's speaking ability
}

\author{
Khoiriyah \\ Universitas Muhammadiyah Jember, Indonesia \\ E-mail: khoiriyah@unmuhjember.ac.id
}

\section{Article History}

Submitted: November 15, 2020

Accepted: January 26, 2021

Published: February 4, 2021

DOI: $10.26555 /$ jecce.v3i2.2589

\begin{abstract}
The implementation of Picture Exchange Communication System (PECS) strategy in this research aimed to improve children's speaking ability. The indicators of speaking ability are child understands the meaning of the word used, able to connect the word to the denoted object, and to pronounce words understood by others. In other word, child is able to repeat sentences, ask questions with the correct sentence, and express opinions to others. This study uses qualitative method with the type of action research. The study was conducted in two cycles, with 3 meetings in each. The design of this study starts from the planning, implementation, observation, and reflection. The participants were 17 children aged 4-5 years old of group A1 TK ABA 4 Mangli Kaliwates Jember. The result showed that prior to PECS the children's speaking development rate was $17 \%$, after the PECS action the speaking ability increased from $35 \%$ in the first cycle to $88 \%$ in second cycle. This shows that the speaking ability of early childhood can be improved with PECS approach.
\end{abstract}

Keywords: Children, Speaking Ability, PECS

\section{Abstrak}

Penerapan Strategi Picture Exchange Communication System (PECS) dalam penelitian ini bertujuan untuk mengembangkan kemampuan bicara anak usia dini. Indikator kemampuan bicara antara lain anak mengerti makna kata yang digunakan, dapat menghubungkan kata tersebut dengan objek yang diwakilinya, mampu mengulang kalimat sederhana, bertanya dengan kalimat yang benar, dan mengutarakan pendapat kepada orang lain. Metode yang digunakan dalam penelitian ini adalah metode kualitatif dengan jenis penelitian action research. Penelitian dilakukan dalam dua siklus, setiap siklus dilakukan 3 kali pertemuan. Tahap yang dilakukan adalah perencanaan, pelaksanaan, observasi, dan refleksi. Subjek dalam penelitian ini adalah 17 anak berusia 4-5 tahun dari kelompok A1 TK ABA 4 Mangli Kaliwates Jember. Hasil penelitian menunjukkan sebelum dilakukan pendekatan PECS tingkat capaian perkembangan bicara anak sebesar 17\%, setelah dilakukan tindakan PECS kemampuan bicara anak meningkat dari 35\% di siklus I menjadi 88\% di siklus II. Dari data tersebut dapat disimpulkan bahwa kemampuan bicara anak usia dini dapat ditingkatkan melalui pendekatan PECS.

Kata Kunci : Anak Usia Dini, Kemampuan Bicara, PECS

\section{INTRODUCTION}

Early childhood education is held as an effort to prepare children before their primary school, in the educational process a stimulus is needed that can help children to grow and develop both physically and spiritually. Meanwhile, the early childhood is an individual at the age of 0-6 years and is experiencing very rapid development. The quality of life at this time 
affects the next life. Montessori stated that early childhood is a child who is in a golden age between the human life span, which is a sensitive period for receiving external stimuli (Sujiono, 2009) .

At that age a child reaches maturation, in both physical and psychological functions, and from here the child is able to respond and show developments in daily behavior. Furthermore, one aspect of child development is communication in the form of language abilities (Sujiono, 2009). One aspect of language is speaking. Speaking is a process of conveying information through language sounds (Suhartono, 2005). In addition, mastery of the desired pronunciation, structure and vocabulary is a factor that may affect good speaking skill (Nurgiantoro, 2016).

Speaking skill of a child is an ability to express articulate sounds or words intended, express thoughts, ideas, or feelings in order to communicate with others. According to Regulation of the Minister of Education and Culture of the Republic of Indonesia Number 137 of 2014 concerning National Standards for Early Childhood Education (2014), the children's speaking skill is considered good if it meets the level of achievement of early childhood language development especially in the language aspect. Such as, they are able to listen to the words of others, recognize word differences, repeat simple sentences, persist with correct sentences, say answers to questions, express opinions to others, and recognize symbols. Therefore the right approach is needed to develop their speaking ability. Before determining the approach, an educator needs to know what factors affect the speaking ability of the children.

Internal and external factors may affect children's speaking ability (Hurlock, 1978). Both factors have a significant effect on children's speaking development. The internal factors are those related to the children's condition, such as health, level of intelligence, gender, and desire to communicate. Meanwhile, external factors are related to environmental conditions. While the environmental conditions are the situations around the child, such as encouragement from adults and training methods for children, as well as relationships with peers.

If these factors are not met, then some disturbances can arise in the child, one of which is a delay in speaking. Speech delays are a disorder state that is often found in children, if not treated immediately it will be more severe (Indriati, 2011). There are many ways or methods to develop a child's speaking. Speaking ability among children can be developed through role playing method (Khoiriyah, 2017). Meanwhile children's speaking skills can also be developed through storytelling using flannel boards (Setiawati \& Ulfah, 2018). Wahyuni, Iswara, and

\begin{tabular}{|l|c|l|}
\hline & Page & \\
\hline & 112 & \\
\hline
\end{tabular}


(Wahyuni et al., 2017) found that the talking stick method assisted by serial image media can improve children's speaking skills by telling their experiences.

Supporting children's speaking skill can be achieved through reading aloud and storytelling can be a pedagogical tool for children's development (Brodin \& Rendblad, 2019). However, this is not the only method that can be used to support communication for children. The development of speaking has increased because of the process of improving the quality of learning, especially in the aspects of speaking development. In addition, the interaction between teacher and students must also be improved. Apart from these methods and approaches, there is another approach may be used to improve speaking skills of the children, namely the Picture Exchange Communication System (PECS). At the beginning, PECS was actually designed to develop speaking skills for children with autism. PECS can be a reference method used to train expressive communication for children with autism. The results showed that there was a significant increase in the value of each child at each phase in the PECS method (Jusoh \& Majid, 2017). The PECS is an important strategy for overcoming communication problems and learning difficulties among children with autism.

The PECS approach uses non-verbal symbols in the form of images as a medium to stimulate communication and to help children spontaneously express communicative interactions and improve their speaking skills. The purpose of using PECS is to help children express communicative interactions spontaneously, so that they can understand the function of communication and develop communication skills (Abidin, 2012).

Originally PECS was designed by Andrew Bondy and Lori Frost in 1985 for children with autism. The PECS method can be a reference method used to train expressive communication for children with autism (Goa \& Derung, 2017). The PECS can improve structured speaking skills for children with autism. Furthermore, it was stated that the increase in structured speaking skills in these participants was related to the provision of some stimulation using visual concepts involving picture cards that had closeness to their daily lives (Vistasari \& Patria, 2019).

Bondy \& Frost explain that the PECS approach has clear objectives, and because it uses images as a medium and does not require prerequisite skills to apply it, and becomes easy to understand (Murwati, 2013). The PECS method can be used as an alternative in training communication for autistic children because it adapts to the communication characteristics and uniqueness of autistic children (Heryati \& Ratnengsih, 2017). Khoiriyah (2020) found that PECS was proven effective in improving communication skills in children with autism, where

\begin{tabular}{|l|c|l|}
\hline & Page & \\
\hline & 113 & \\
\hline
\end{tabular}


children can respond to what the teacher said by showing expressions and being able to understand what was ordered and can express wishes with simple sentences that can be understood by others.

PECS users are those who have poorly developed language skills, as well as those who do not have the will to communicate with others (Murwati, 2013). In line with that, Trimailani et al., (2015) emphasized that the use of PECS has a positive effect on increasing the communication skills of deaf children who have problems in pronouncing words.

Based on the opinions and experiences of these experts, it is known that PECS is quite effective in improving speaking skills of children who have speech deficiencies. Although generally PECS is applied to children with special need, in its development PECS has begun to be developed and used as an approach to improve children's speaking skills in early childhood education institutions. Through the PECS method, children do not feel that they are actually learning to read, because children are presented with a picture, not a line of text or letters. The images presented on the cards can attract children's attention, so they want to know the pictures on the cards. In this learning process, it cannot be separated from the principles of children's learning, namely learning while playing (Ariyanti, 2018).

One of the early childhood education institutions in this study is TK ABA 4 Mangli, Kaliwates Jember. The Researcher use PECS to assist early childhood teacher in developing children's speaking skills, with the aim of obtaining data on the extent to which the PECS approach can develop early childhood speaking skills.

\section{METODE}

This study uses action research method related to social practice, problem solving, and improvement in the reflective process. Action research is a process that allows teacher to improve learning, and teacher can carry out learning in new ways (Sagor, 1992). The purpose of action research is to develop new approaches to solving problems with direct application (Suryabrata, 2018). In other words, action research as research that deals with problem solving that allows teacher to enhance learning in new ways. To help teacher develop early childhood speaking skills, the researcher used the Picture Exchange Communication System (PECS) approach by taking collaborative actions with teacher at TK ABA 4 Mangli Kaliwates Jember with 17 children as subjects.

The research is carried out in stages, starting from planning, implementing, observing, and reflecting. The first stage started with planning, in which there were three basic activities,

\begin{tabular}{|l|c|l|}
\hline & Page & \\
\hline & 114 & \\
\hline
\end{tabular}


namely problem identification, problem formulation, and problem solving. The problems occured among children of group A1 TK ABA 4 Mangli: the children's speaking ability has not developed optimally, with indicators of their lack of ability to convey opinions to others, repeating simple sentences and not being able to make simple sentences from some of the pictures shown by the teacher. From these problems, the researcher designed learning using the PECS approach.

The second stage is implementation. In this stage the researcher applied what has been planned, namely the researcher and the teacher provided picture cards that have been adjusted to the theme. After that the children were invited to take 4 picture cards and stick them on the sticky board, then the teacher asked the question: why do you choose this picture? With these questions, it the children should be able to answer with simple sentences and convey opinions to others.

The third stage is observation. This stage is a tool to get an idea of how far the action has reached the target. Based on the results of observations in the first cycle carried out in group A1 with a total of 17 children consisting of 9 male and 8 female, only 6 children were active and in accordance with expectations, the six children were able to convey their opinions and compose simple sentences from the pictures they chose. Meanwhile, the 10 children were only able to say the words of the pictures they chose. Based on the results of these observations, the teacher and researcher revised the activities to take further actions.

The last stage is reflection. This stage contains activities to study and analyze the results of observations, to find out weaknesses to be fixed. In the previous stage the children had difficulty understanding and mentioning the pictures they chose. Therefore, at this reflection stage, the teacher improved the activity by explaining each picture on the card, to make it easier for children to compose simple sentences from the pictures they chose. The PECS approach activities can be seen at figure 1.

The completeness criteria carried out by researchers at TK ABA 4 Mangli Kaliwates Jember, namely: (1) Children were able to call the picture they choose, (2) Children were able to answer questions according to questions, (3) Children were able to express opinions based on the pictures they choose . (4) Children were able to state the reasons why they chose the pictures, and (5) Children were able to make simple sentences from the pictures they chose.

\begin{tabular}{|l|c|l|}
\hline & Page & \\
\hline & 115 & \\
\hline
\end{tabular}




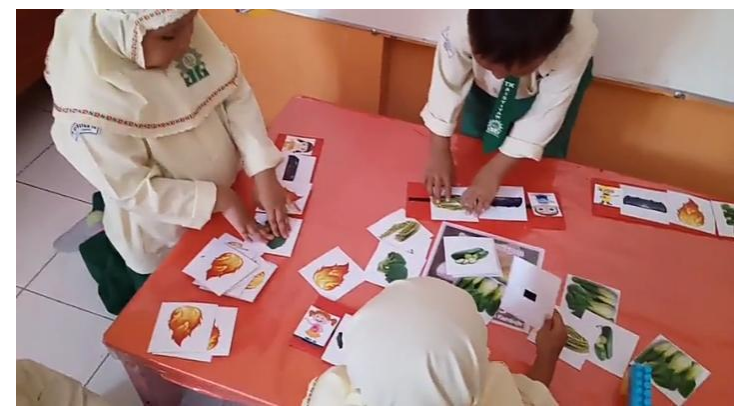

Figure 1. PECS Approach Activities

Data collection in this study was carried out through observation, interviews, notes and recordings. Data from observations were obtained during activities in cycles I and II, and the data from interviews were obtained as long as researchers communicated with children and class teacher. Data from notes and recordings were obtained during learning activities. In this observation the researcher used qualitative data analysis which was used to determine the increase of the children's speaking ability from each action taken by the teacher. The researcher got the results of data analysis from the reflection stage during the observation activities. This reflection showed conclusion about what should be improved in the next activity.

The instrument used in the observation contained a sheet of check list in the form of the observed aspects. The success criteria used are classical and individual one. Individually, children are declared complete if they have received a star $\left({ }^{* * *}\right)$ from 5 indicators. There were 5 indicators in this observation, so the score that must be achieved by each child who considered complete was $\left.5 \times 3=15{ }^{* * *}\right)$. In classical terms, $75 \%$ of the 17 children, namely 14 children, have received scores or stars $\left(^{* *}\right)$ in each indicator or the total score of 15 . Meanwhile, the data analysis used was qualitative in order to determine the effect of the PECS approach in developing children's speaking ability.

\section{RESULTS AND DISCUSSION}

Children's speaking skill is the children's ability to understand the meaning of the words used and be able to relate them to objects called with the words, children's ability to mention known picture, children's ability to answer questions according to what asked, to express opinions to others, include reasons for what they want or don't want, and their ability to make simple sentences from the selected object. Based on Regulation of the Minister of Education and Culture of the Republic of Indonesia Number 137 of 2014 concerning National

\begin{tabular}{|l|c|l|}
\hline & Page & \\
\hline & 116 & \\
\hline
\end{tabular}


Standards for Early Childhood Education (2014) the abilities of children in the 4-5 year age group in the Language Aspect shown at table 1.

Table 1. Developmental Achievement Levels of Children aged 4-5 Years

Scope of Development

Language
A. Understanding Language
B. Expressing Language

1. Listening to what other people say (mother tongue or other language)

2. Understand the two commands given at the same time

3. Know the vocabulary Regarding adjectives

1. Repeating a simple sentence

2. Ask the correct sentence

3. Answering questions according to questions

4. Express feelings with adjectives (good, happy, naughty, stingy, kind, brave, good, bad, etc.)

5. Mention familiar words

6. Express opinions to others

C. Literacy
1. Recognizing symbols

2. Make meaningful scribbles

3. Imitating (writing and pronouncing) the letters A-Z

Before taking action, the researcher as an observer first checked the field situation and looked for data before taking further action. The observer conducted assessment during direct learning by looking at the children's speaking ability. The assessment was carried out with three criteria: a 3-star score if the child is able to do the task well in question, a score of 2 if the child is able to do the task but there are still errors, and a score of 1 if the child has not done the task in question. Based on observations of the results of children's work, there were 3 children or $17 \%$ of 17 children who achieved completeness and according to the target assessment. The rest of the children were only able to answer questions with one word only.

From these observations, it is known that the obstacles experienced by the children of TK ABA 4 Mangli Kaliwates Jember in developing speaking skills are as follows:

1. Teacher do not understand how to improve children's speaking ability, which is indicated by learning activities that are still in teacher-centered, so the children are not too active in expressing themselves and expressing opinions, because the activities have been prepared by the teacher and the children as implementers only.

2. Children have not mastered a lot of vocabulary, so they find it difficult to name objects or make simple sentences from these objects.

3. Children are still hesitant in expressing their opinions, this is due to the habits of teacher who intervene in what children do.

\begin{tabular}{|l|c|l|}
\hline & Page & \\
\hline & 117 & \\
\hline
\end{tabular}


The solutions to improve children's speaking skills can be done through the PECS approach, where children will be facilitated by various media and activities that make them more active in communicating and improve their speaking skills. The Pictures Exchange Communication System (PECS) approach here is carried out through cycles. Each cycle consists of three meetings, in which an assessment of success is assessed so that it can be seen that there has been an increase from the initial score.

The planning stage in the first cycle, the researcher explained to the teacher the importance of developing children's speaking skills. Then the next stage the researcher explained about the PECS approach and how to apply it. When the teacher got understanding and approved of the activity, the researcher proceeded to the next stage, namely implementation, which was carried out for three meetings. Each meeting is carried out following the Standard Oprating Procedure (SOP) set by the school, with learning activities using the PECS approach. In this observation, the teacher acted as implementers and researcher as an observer.

Based on the results of observations during the implementation of PECS as shown at figure 2 , children still have difficulty mentioning the names of the pictures on the cards, which causes them to have difficulty making simple sentences. Out of 17 children, only 10 were able to name the pictures they chose. So that in cycle I it can be said that indicator 1 has not been fulfilled. Another problem that can be seen that the children still have difficulty in making simple sentences and stating their reasons for choosing the picture, one of them was Rn, he was not able to make a simple sentence from the pictures in his hand, he only say words from the pictures.

The other 5 children also experienced the same, after being observed it happened because of the teacher's lack of explanation on how to make simple sentences at the beginning before carrying out the density: composing pictures, conveying the reasons for choosing the pictures, and making simple sentences from the selected pictures. So, the indicator 2 in cycle I has not been fulfilled. Another problem the researcher encountered in cycle I was that children still hesitant to express their opinion about the pictures they chose, one of them was Fn male 5year-old, who was shy and hesitant when taught to make simple sentences, he was just silent and hesitated to speak, so that in this case indicators 3 and 4 have not been met. From the observation, that it happened because the children were not used to it and the teacher is still not proficient in stimulating children to actively speak and express their opinions. So that the indicators 1-5 in this observation have not been achieved optimally. Qualitatively, the following is an increase in children's speech through the PECS approach in cycle 1. There are 6 children

\begin{tabular}{|l|c|c|}
\hline & Page & \\
118 & \\
\hline
\end{tabular}


who have met the completeness criteria, and there are 11 children who have not met the completeness criteria. This means that classical completeness has only reached $35 \%$. Table 2 is the observation data of cycle I:

Table 2. Data Cycle 1

\begin{tabular}{|c|c|c|}
\hline \multirow{2}{*}{$\begin{array}{c}\text { Information } \\
\text { Cycle }\end{array}$} & \multicolumn{2}{|c|}{ Completeness Percentage } \\
\hline & Completed & Not Completed \\
\hline Cycle I & $35 \%$ & $65 \%$ \\
\hline
\end{tabular}

Based on the data of the table, the percentage of children who reach the completeness criteria is only $35 \%$, while the completeness standard in this observation is $75 \%$. So it can be concluded that the observation have not reached the completeness criteria and need to be improved and applied in the next cycle. Several evaluations that need to be fixed and applied in cycle II that are 1) The teacher should to enrich the children's vocabs by first explaining the name of the picture on the cards; 2) The teacher should to try to stimulate children to actively speak and communicate by asking children's opinions about what they are doing; 3) The teacher should to make better preparation, especially in teaching media; 4) The teacher should to provide clear and understandable pictures for the children; 5) The teacher should to facilitate and give children more opportunities to express themselves; and 6) The teacher should not intervene much in what children do.

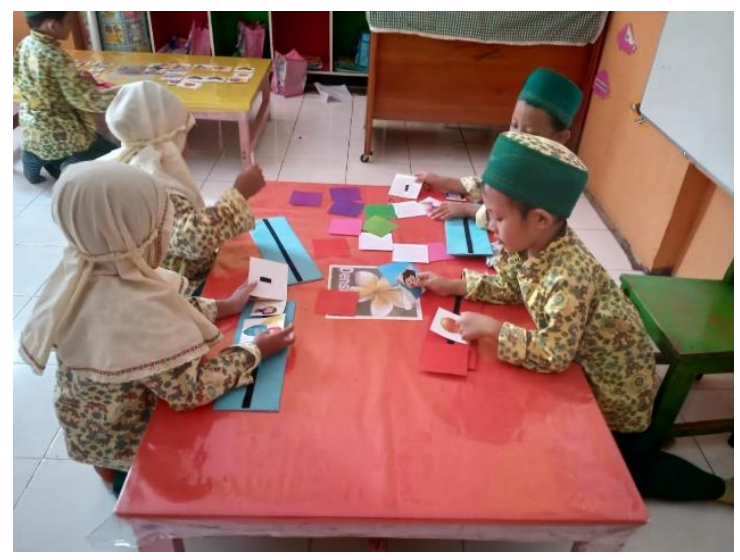

Figure 2. Cycle I of the PECS Approach

In cycle II, this research was carried out with the same stages starting from planning up to implementation, which were carried out for three meetings by applying the improvements that have been designed. During the three meetings, the implementation of PECS went smoothly, the children were able to adapt to the activities, their vocabs mastery began to improve and they were more confident in delivering simple sentences from the pictures they chose.

\begin{tabular}{|l|c|l|}
\hline & Page & \\
\hline & 119 & \\
\hline
\end{tabular}


In cycle II, the children found experienced a significant increase and reached indicator 1, which was able to mention pictures (vocabulary), this was because the teacher explained names from the pictures on the card one by one. The explanations were also repeated until understood by the children. Although there were some children who have difficulty in pronouncing the words from the pictures on the cards. For example, at meeting 2, Fn called broccoli with brokodel.

The children's ability to understand teacher's questions began to increase in cycle II. They have been able to answer the teacher's questions correctly related to the questions, this has reached indicator 2 . The children were also able to reach indicators 3 and 4 , namely expressing opinions to others and expressing reasons for what they want or don't want. This could be seen when they answered the teacher's questions about the reasons why they chose the picture card and made simple sentences from the pictures choosen. After repeated training, children were able to make simple sentences related to the pictures they chose according to the structures: subjects, predicates, objects, and descriptions. This is because of the teacher trained the children to try repeatedly until they achieved the 5 indicators and criteria for success of the PECS approach.

From the second cycle carried out, the learning outcomes improved speaking ability through the PECS approach, children who had met the completeness criteria, namely 15 children had received 3 stars on each indicator. Thus, the total number of scores on all indicators per child is 15 . Based on the table above, it can be seen that the classical increase in children who get 3 stars in each aspect is 15 children (88\%).

From the results of the research in cycle II which was carried out for three meetings, it can be concluded that these results have reached the completeness standard, both the individual completeness criteria, namely 15 children get a 3 star score in each indicator with a total score of 15 stars, as well as the classical completeness criteria, namely 15 children out of 17 (88\%). Thus, this observation activity has exceeded the predetermined completeness standard 75\%. Table 3 is a table data of improvement of each cycle of the PECS approach.

Table 3. Data on the PECS Approach Cycles

\begin{tabular}{lc}
\hline Information & Percentage of Completeness \\
\hline Preliminary studies & $17 \%$ \\
Cycle I & $35 \%$ \\
Cycle II & $88 \%$ \\
\hline
\end{tabular}

\begin{tabular}{|l|c|l|}
\hline & Page & \\
\hline & 120 & \\
\hline
\end{tabular}


From the observation data, it is concluded that in the preliminary study there were 3 children who achieved completeness as $17 \%$ of 17 children. In cycle 1 there was an increase in 6 children as $35 \%$, and in cycle 2 there were 15 children who achieved completeness as $88 \%$ of 17 children. The changes made by the teacher and the progress after implementing PECS approach are:

1. Before implementing the strategy through PECS approach, learning activities did not develop children's speaking skills and learning activities were often carried out using the lecture method. So that the children's opportunity to realize themselves and express their opinions is limited.

2. Before the implementation of PECS, the teacher only provide learning activities in the form of drawing, coloring, and writing letters. After knowing PECS approach, they were inspired to develop learning activities by optimizing children's speaking skills using more interesting media, not only coloring and drawing.

The above shows that children's speaking skills can be improved through the Picture Exchange Communication System (PECS) approach.

\section{CONCLUSION}

Based on these results, the PECS approach can improve children's speaking skills. This increase can be seen from the indicators of the child being able to mention words for pictures (vocabulary), answer correctly related to questions, express opinions to others, express reasons for what they want or do not want, and are able to make simple sentences from the selected pictures.

The most important things that determine the success of implementing this PECS strategy are: (1) The teacher stimulates children to actively speak by providing opportunities to express themselves, (2) The teacher must not intervene in what the children do, so that the they grow confidently, (3) The theme chosen is something interesting and familiar to children, (4) The picture must be clear enough to indicate an object, (5) The size of the pictures must be proportional, not too small nor too big.

\begin{tabular}{|l|c|c|}
\hline & Page & \\
\hline & 121 & \\
\hline
\end{tabular}




\section{REFERENSI}

Abiddin, Z., \& Haryana. (2012). Pengembangan Komunikasi Anak Autis Melalui PECS. Kementerian Pendidikan dan Kebudayaan: Badan Pemberdayaan Penjaminan Mutu dan Sumber Daya Kependidikan. Pusat Pengembangan dan pemberdayaan Pendidikan dan Tenaga Kependidikan.

Ariyanti, R. (2018). Pengenalan Membaca Awal Dengan Metode PECS Untuk Anak Usia Dini 2 3 Tahun Abstrack. Sendika FKIP UAD, I/(1), 283-287.

Brodin, J., \& Rendblad, K. (2019). Improvement of preschool children's speech and language skills. Early Child Development and Care, 19014), 2205-2213. https://doi.org/10.1080/03004430.2018.1564917

Goa, L., \& Derung, T. N. (2017). Komunikasi Ekspresif Dengan Metode Pecs Bagi Anak Dengan Autis. Jurnal Nomosleca, 3(2), 625-634. https://doi.org/10.26905/nomosleca.v3i2.2037

Heryati, E., \& Ratnengsih, E. (2017). Penggunaan Metode Pecs (Picture Exchange Communication System) Untuk Meningkatkan Kemampuan Komunikasi Anak Autis. Pedagogia, 15(1), 31-38. https://doi.org/10.17509/pedagogia.v15i1.6558

Hurlock, E. B. (1978). Perkembangan Anak(1 sd 6). Erlangga.

Indriati, E. (2011). Kesulitan bicara dan berbahasa pada anak (1st ed.). Prenada.

Jusoh, W., \& Majid, R. A. (2017). Using Picture Exchange Communication System To Improve Speech Utterance Among Children With Autism. Journal of ICSAR, 1(1), 46-49. https://doi.org/10.17977/um005v1i12017p046

Khoiriyah, K. (2017). Improving the Children's Speaking Ability through Role Playing Method. Indonesian Journal of Early Childhood Education Studies, 6(2), 100-107. https://doi.org/10.15294/ijeces.v6i2.20203

Khoiriyah, K. (2020). Picture Exchange Communication System (PECS) Sebuah Strategi Pengoptimalan Kemampuan Komunikasi Anak Autis. Jurnal Buah Hati, 71), 39-51. https://doi.org/10.46244/buahhati.v7i1.938

Murwati, A. (2013). Meningkatkan Kemampuan Komunikasi Pada Anak Autis Melalui Media PECS (Picture Exchange Communication System). Universitas Muhammadiyah Surakarta.

Nurgiantoro, B. (2016). Penilaian Pembelajaran Bahasa Berbasis Kompetensi. Fakultas Ekonomika \& Bisnis UGM.

\begin{tabular}{|l|c|l|}
\hline & Page & \\
\hline & 122 & \\
\hline
\end{tabular}


Peraturan Menteri Pendidikan Dan Kebudayaan Republik Indonesia Nomor 137 Tahun 2014 Tentang Standar Nasional Pendidikan Anak Usia Dini. (2014). In Kemendikbud.

Sagor, R. (1992). How to Conduct Collaborative Action Research. In Journal of Chemical Information and Modeling (Vol. 53, Issue 9). Association for Supervision and Curriculum Development.

Setiawati, E., \& Ulfah, A. (2018). Meningkatkan Perkembangan Berbicara Anak Melalui Bercerita Menggunakan Flannel Boards. Cakrawala Dini: Jurnal Pendidikan Anak Usia Dini, 92), 98-109. https://doi.org/10.17509/cd.v9i2.13439

Suhartono, S. (2005). Pengembangan keterampilan bicara anak usia dini. Depdiknas RI.

Sujiono, Y. N. (2009). Konsep Dasar Pendidikan Anak Usia Dini(1st ed.). PT Indeks.

Suryabrata, S. (2018). Metodologi Penelitian(28th ed.). Raja Grafindo Persada.

Trimailani, R., Armaini, A., \& Damri, D. (2015). Efektifitas Pecs Untuk Meningkatkan Kemampuan Komunikasi Anak Tunarungu Kelas Vii Smplb (Single Subject Research Di SIb Ypplb Padang). Jurnal Penelitian Pendidikan Khusus, 4(3), 445-452. https://doi.org/10.24036/jupe70930.64

Vistasari, R., \& Patria, B. (2019). Program PECS (Picture Exchange Communication System) untuk Meningkatkan Kemampuan Berbicara Terstruktur pada Anak Autis. Gadjah Mada Journal of Professional Psychology (GamaJPP), 5(1), 94-107. https://doi.org/10.22146/gamajpp.48590

Wahyuni, I. F., Iswara, D. P., \& Sunaengsih, C. (2017). Upaya Meningkatkan Kemampuan Berbicara Siswa Dalam Menceritakan Peristiwa Yang Dialami Menggunakan Metode Talking Stick Berbantuan Media Gambar Seri. Jurnal Pena IImiah, 2(1), 1541-1550. https://doi.org/10.17509/jpi.v2i1.10467

\begin{tabular}{|l|c|l|}
\hline & Page & \\
\hline & 123 & \\
\hline
\end{tabular}

